\title{
The School Environmental Factors That Affect the Academic Performance of Senior High Financial Accounting Students In Tamale Metropolis in The Northern Region of Ghana
}

\author{
Osei -Tutu Joseph \\ Faculty of Education \\ University for Development Studies-Tamale, Ghana \\ Kate Yeboah-Appiagyei \\ Department of Education \\ Valley view University, Ghana \\ Darkwa Bernard Fentim \\ Department of Arts \& Social Sciences Education \\ University of Cape Coast, Ghana
}

\begin{abstract}
The purpose of this paper was to examine the school environmental factors that affect the academic performance of Senior High financial accounting students in the Tamale Metropolis of Ghana. Twenty nine (29) teachers and two hundred and sixty (260) financial accounting students from the seven (7) senior high schools in the metropolis were selected for the study. It was a descriptive study where questionnaire was used to collect the data. The study revealed that availability of residential facilities in schools and instructional materials have a positive influence on the level of students' academic performance in financial accounting. Students who have access to relevant instructional materials such as recommended text books, ICT and library facilities use those materials to supplement their learning endeavours. The study also recommended that, government should put policy framework and structures in place in order to provide residential facilities to most day schools, if not all, and provide those schools with the necessary residential facilities.
\end{abstract}

Keywords: Environmental Factors, Academic Performance, Financial Accounting.

\section{INTRODUCTION}

Education is the bedrock for all future development. This assertion means that education is an important tool for ensuring the continued growth of all nations. Asiedu-Akrofi (1978) concurs that "what the citizens of a country become is dependent upon the sort of education offered them" (p. 1). According to Lockheed and Vespoor (1991), the future development of the World and individual nations hinges more than ever on the capacity of individuals and countries to acquire, adapt and advance knowledge. This capacity depends on whether the population has attained the required skills and knowledge needed to expand and make desired improvement.

Education is the process of imparting to the younger generation, knowledge, values, skills and attitudes that will enable them to play various active roles in the society in which they find themselves (Taba, 1962). The knowledge, values, skills and attitudes required of the younger 
generation are expressed in the philosophy of education or the goal of education of the country. These goals or philosophy of education are translated into practical use through a medium called curriculum (Abosi \& Brookman-Amissah, 1992).

It should be noted that the educational goals of a country are normally linked with its problems, requirements, needs and aspirations. There was the need to keep proper records and ensure sound management of the use of economic resources, by way of ensuring efficiency in operations and effective use of resources. This called for the introduction of accounting as a programme of study into the educational system. In Ghana, Financial Accounting curriculum has been developed into teaching syllabus by the Curriculum Research and Development Division (CRDD) of the Ministry of Education (MOE). In the teaching syllabus are the justifications for the introduction of Financial Accounting into the Senior High Schools curriculum of the Ghana education system. Among them are: the need to provide accurate information for improvement in the efficiency of the economic sector for the country's development. Again, the growth and expansion of business institutions in the country have necessitated the need to train more qualified people to meet the demand, by way of helping in the sound management of these institutions (both profit and not-profit orientated organisations); to increase the numeracy skills of students to help prepare them for further studies in business at the higher level.

Another justification is its requirement for the immediate employment and lifelong career enrichment such as Accountants, Bankers, Auditors, Financial Analysts, Tax Consultants and Management Consultants among others (Ministry of Education, 2008). However various educational research studies have shown that students' academic performance in a subject is a function of several interactive factors. These factors constantly interact in the school environment and therefore determine how good or bad a student may perform in his or her academic pursuit. Figure 1 clearly illustrates the determinants of students' academic performance.

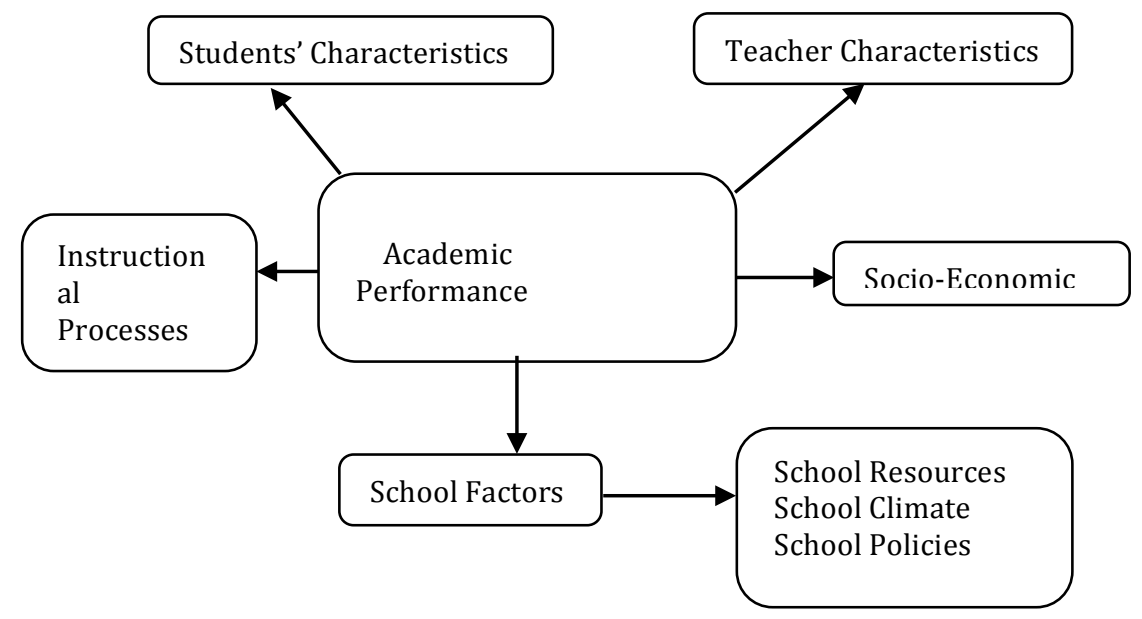

Figure 1: Determinants of Academic Performance of Students

\section{Theory of Correlates of Effective Schools}

The output of students, as reflected on their test scores from series of assessment is the measure of their academic achievement. Several factors influence the academic achievement of students, among which is the school environment which differs from one school to the other. Some schools perform better than others. However, research has identified certain factors that 
make a school more effective in improving the academic performance of students. These factors are called the correlates of effective schools because; the unique characteristics of the majority of effective schools are correlated with student success (Lezotte, 1991).

The correlates of effective schools, which was formally referred to as "five factor theory" because of five elements identified to affect school effectiveness, now comprises seven elements. According to Kirk \& Jones (2004) these correlates are the means to achieving high and equitable levels of student learning. The Correlates are: Clear School Mission; High Expectations for Success; Instructional Leadership; Opportunity to Learn and Time on Task; Safe and Orderly Environment; Positive Home-School Relations; and Frequent Monitoring of Student Progress.

A study of the trend of West Africa Senior School Certificate Examination (WASSCE) performance by Financial Accounting students from the year 2006 to the year 2009 indicated an unstable trend in the students' performance. The average pass rate for the years under review of just 53.6\% (WAEC, 2007-2010) was very worrying and called for further probing as to why amid all efforts on improving the quality of education in the country, the performance of students, particularly Financial Accounting students was still very poor. If an insight is taken into the disparity, one would observe that some schools perform excellently while others perform very poorly. On investigating into what could account for this disparity, an observation one is likely to make is that school environments differ, and this difference is likely to affect students' performance.

In Ghana, school environmental factors leave much to be desired. Conference of Heads of Assisted Secondary Schools (CHASS) also noted the uneven sharing of resources to senior secondary schools, especially business, by the Ghana Education Trust Fund Secretariat (EssahHienno, 2005). Infrastructural development in schools is also unequally shared and this has affected the quality of education in the country. Mr. Paul Evans Aidoo, the then regional minister of Western Region noted that poor educational infrastructure and the attitude of some stakeholders in education negatively affected the quality of education (Dadzie, 2010). Whereas some schools are well resourced in terms of infrastructure, personnel and instructional materials inter alia, others have inadequate classrooms. The least said among personnel and teaching learning materials, the better.

It is in view of these and other reasons that this study was designed to investigate the school environment variables and their possible effects on the performance of the SHS Financial Accounting students in schools in the Tamale Metropolis in the Northern region of Ghana.

The study sought to examine the critical factors in the school environment that affect the performance of students in Financial Accounting in the Tamale Metropolis of the Northern region of Ghana and suggests ways of improving upon the conditions of learning at the Senior High School level. Specifically, the objectives of the study were to:

1. Determine the extent to which the availability of instructional materials affects Financial Accounting student's academic performance.

2. Examine how the availability of residential facilities affects performance of the Financial Accounting students.

3. Investigate the effect of class size on the academic performance of Financial Accounting students. 


\section{Research Question}

The study sought answers to the following research question:

How does the availability of instructional materials affect students' performance in Financial Accounting?

\section{Research Hypotheses}

The study was guided by the following hypotheses:

1. H0: There is no significant difference in academic performance in Financial Accounting between students with residential facilities and students without residential facilities.

H1: There is a significant difference in academic performance in Financial Accounting between students with residential facilities and students without residential facilities.

2. H0: There is no significant relationship between class size and academic performance of students in Financial Accounting.

H1: There is a significant relationship between class size and academic performance of students in Financial Accounting.

\section{METHODOLOGY}

The design used for this study was the descriptive survey research design. According to Best \& Kahn (1993), "descriptive research deals with the relationships among non-manipulative variables, since the events or conditions have already occurred" (p. 20). McMillan (1996) also contended that a descriptive survey research essentially describes existing phenomena without changing some conditions to affect subjects' responses. This design was selected because it enabled data to be collected in order to test the hypotheses or answer questions concerning the current status of the school environment variables of SHS in the Tamale Metropolis of Ghana and possible effects of these variables on students' performance in Financial Accounting.

The population of the study comprised Financial Accounting students and teachers of public senior high schools in the Tamale Metropolis of Ghana. The area of the study was the Tamale Metropolis within the Northern Region of Ghana. The target group for the study consisted of 800 Financial Accounting students and 29 Financial Accounting teachers. The 800 students were all final (fourth) year Financial Accounting students. The final year students have stayed in the school environment and studied the subject (Financial Accounting) in a number of years. As a consequence, this group of students were in a better position to provide valuable information concerning the topic under investigation. The population for the study is depicted by the Table 1.

The sample that was used for the study comprised 260 Financial Accounting students and 29 Financial Accounting teachers in the selected schools. The selection of the 260 students was done by using the table for determining a sample size from a given population. According to Krejcie and Morgan (as cited in Sarantakos, 1998), for a given population of 800, the appropriate sample size for research exercise should be 260 respondents. 
Table 1: Population for the Study

\begin{tabular}{lcc}
\hline Name of school & Students & Teachers \\
\hline Northern Business SHS & 185 & 7 \\
Business SHS & 173 & 6 \\
Ghana SHS & 120 & 5 \\
Tamale SHS & 117 & 4 \\
Tamale Girls SHS & 110 & 4 \\
Kalpohine SHS & 95 & 3 \\
\hline Total & 800 & 29 \\
\hline
\end{tabular}

Source: Field work (2011)

A multi-stage sampling technique was used to select the sample for the study. The simple random technique was used to select the 260 Financial Accounting students while the census survey was employed to collect the 29 Financial Accounting teachers. The lottery method of the simple random sampling technique was used. This gave every Financial Accounting student an equal and independent chance of being selected to participate in the study.

Two sets of researcher-developed questionnaire and Financial Accounting Achievement Test were the two instruments used to collect data from the Financial Accounting Teachers and Financial Accounting Students in the Tamale Metropolitan area. While the Financial Accounting achievement test was used to measure the dependent variable (students' performance in Financial Accounting), the questionnaire sought information on teachers' and students' background data (name of school, gender, teachers' level of qualification, teachers' experience) and the independent variables (class size, adequacy of instructional materials and residential facilities) that influence the level of students' performance.

Data collected for the study were analysed with the aid of Statistical Package for Service Solutions (SPSS) computer application software. The dependent variable was senior high schools students' performance in Financial Accounting and the independent variables were change of school environmental variables reflected in class size, instructional materials and residential facilities. Reponses to the research questions and the hypotheses were analysed as follows: Descriptive statistics (frequencies, percentages, means and standard deviation) were used to analyse the data for research question one: To what extent does the availability of adequate instructional materials improve students' performance in Financial Accounting?

Independent samples t- test was used to analyse the data on research hypothesis one. This allowed for mean scores between the two groups of Financial Accounting students to be compared. The data concerning research hypothesis two were analyzed through the use of both simple linear regression and simple descriptive statistics.

\section{RESULTS AND DISCUSSION}

Research Question 1: How availability of instructional materials affect students' performance in Financial Accounting

This question was posed to examine how the availability of teaching and learning materials affects the academic performance of students in Financial Accounting. Items 7-14 of the questionnaire for financial accounting students and items 24-31 of the questionnaire for the financial accounting teachers were developed to answer this research question. Descriptive 
statistics (frequencies, percentages, means and standard deviations) were used to analyze the responses on how the use of instructional resources can affect students' learning and achievement in the subjects. The results are shown in Table 2.

Table 2: Students' Views Concerning the Influence of Instructional Materials on Learning Process

\begin{tabular}{|c|c|c|c|c|c|}
\hline \multirow[t]{2}{*}{ Statement } & V. True & True & N. True & \multirow[t]{2}{*}{$\mathbf{M}$} & \multirow[t]{2}{*}{ SD } \\
\hline & $\mathrm{N} \%$ & $\mathrm{~N} \%$ & $\mathbf{N} \%$ & & \\
\hline $\begin{array}{l}\text { Availability of recommended textbooks } \\
\text { enhances my performance }\end{array}$ & $180(76.3)$ & $54(22.9)$ & $2(0.8)$ & 2.85 & .56 \\
\hline Graphs books enables me to study effectively & $185(78.4)$ & $47(19.9)$ & $4(1.7)$ & 2.7 & .86 \\
\hline $\begin{array}{l}\text { Chalkboard and its accessories facilitate my } \\
\text { learning }\end{array}$ & $56(23.7)$ & $73(30.9)$ & $107(45.3)$ & 1.4 & .71 \\
\hline $\begin{array}{l}\text { Availability of library facilities helps to improve } \\
\text { my performance }\end{array}$ & 205(86.9) & $23(9.7)$ & $8(3.4)$ & 2.95 & .54 \\
\hline $\begin{array}{l}\text { Availability of ICT facilities enables me to } \\
\text { perform well }\end{array}$ & $184(78.0)$ & $45(17.0)$ & $7(3.0)$ & 2.67 & .84 \\
\hline $\begin{array}{l}\text { Availability of instructional materials improves } \\
\text { students' performance }\end{array}$ & $209(88.6)$ & $27(11.4)$ & $0(0)$ & 2.97 & .47 \\
\hline
\end{tabular}

Source: Field work (2011)

$N B:$ V = Very; $N=$ Not Very True $=2.5-3.0$;

True $=1.5-2.4 ;$ Not True $=1.0-1.5$

The results in Table 2 indicate that a majority of the students were of the view that the availability of recommended textbooks in Financial Accounting can help to improve the academic performance of students in the subject $(\mathrm{M}=2.85, \mathrm{SD}=.56)$. The study also reveals that students were of the view that the existence of recommended text books enabled them to study effectively. This means that the availability of the recommended and reference Financial Accounting textbooks influences the level of students' performance. This is consistent with the earlier finding of researchers (Fuller, 1985; Eshiwani, 1986; Walstad \& Rebeck, 2001; Atanda \& Jaiyeoba, 1998) that the availability of textbooks enhances students' performance in their learning pursuit.

Moreover, the students were in support of the ideas that the availability of ICT and library facilities (as shown by $\mathrm{M}=2.67 ; \mathrm{SD}=.84$ and $\mathrm{M}=2.95 ; \mathrm{SD}=.54$ respectively) could help to improve upon their academic performance in the study of Financial Accounting. This suggests that ICT and library facilities serve as complement to the recommended textbooks and other reading materials that are necessary for the teaching and learning of Financial Accounting at the Senior High School level. With the presence of such facilities, the students can resort to them in order to make further research on the subject area. In support of this recent finding, Owoeye and Yara (2011) found that the availability of library facilities correlated with students' performance. The present result on the positive influence of ICT facilities contradicts the earlier finding of Becta (2002), who found no consistent relationship between the average 
amount of ICT use reported for any subject at a given key stage and its apparent effectiveness in raising academic standards among students.

This suggests that the availability of instructional materials has a positive influence on the level of students' academic performance in the subject. This finding is consistent with the view that the greater quantity of instructional materials, the greater the level of students' performance in Financial Accounting. The present study confirms the previous findings of earlier researchers (Suydam \& Higgins, 1977; Sowell, 1989; Grouws \& Cebulla, 2000; Jekayinfa, n. d; Owoeye \& Yara, 2011) that the presence and use of instructional materials can contribute to students' academic performance in various disciplines.

Research Hypothesis 1: There is no significant difference in academic performance between students with residential facilities and students without residential facilities.

This hypothesis was posed to help determine whether there is any significant difference in academic performance between students in schools with residential facilities and those without residential facilities. Table 3 shows the descriptive statistics concerning the various residential facilities.

Table 3: Teachers' and Students' Views Concerning the Adequacy of Various Residential Facilities

\begin{tabular}{|c|c|c|c|c|}
\hline \multirow{4}{*}{ Residential Facility } & \multirow{3}{*}{\multicolumn{2}{|c|}{$\begin{array}{l}\text { Teachers' Responses } \\
\text { Adequate } \\
\text { Inadequate }\end{array}$}} & \multirow{2}{*}{\multicolumn{2}{|c|}{$\begin{array}{l}\text { Students' Responses } \\
\text { Adequate }\end{array}$}} \\
\hline & & & & Inadequate \\
\hline & & & \multirow[t]{2}{*}{$\mathrm{N} \%$} & \multirow{2}{*}{$\mathrm{N} \%$} \\
\hline & $\mathrm{N} \%$ & $\%$ & & \\
\hline Beddings & $9(31.0)$ & $20(69.0)$ & $32(13.6)$ & $204(86.4)$ \\
\hline Study areas & $7(24.1)$ & $22(75.9)$ & $33(14.0)$ & $203(86.0)$ \\
\hline Recreational areas & $8(27.6)$ & $21(72.4)$ & $14(0.9)$ & $222(94.1)$ \\
\hline Dormitories & $11(37.9)$ & $18(62.1)$ & $18(7.6)$ & $218(92.4)$ \\
\hline Dining Hall & $13(44.8)$ & $16(55.2)$ & $51(21.6)$ & $185(78.4)$ \\
\hline Lavatory Facilities & $5(17.2)$ & $24(82.8)$ & $4(1.7)$ & $232(98.3)$ \\
\hline
\end{tabular}

Source: Field work (2011)

The results as shown in Table 3 indicate that most of the second cycle institutions in the Tamale Metropolis do not have adequate supply of the necessary residential facilities that are needed to assist residential students to undertake their studies successfully. Both the Financial Accounting teachers and students who participated in the study were of the view that such residential facilities as beddings, study recreational areas, dormitories, dining halls and lavatories were inadequate in the selected senior high schools. This implies that students in the boarding house might face some difficulties in their studies and this will impact negatively on their overall academic standards in Financial Accounting. On their part, Bourner and Race (1990) found that students with inadequate residential facilities tend to juggle their academic work and other environmental responsibilities which can incapacitate their educational gains.

In furtherance to the above results, an independent samples t-test was used to find out the differences, if any, between the two groups of students. Leveve's test for homogeneity of variance for the two samples was conducted. Outcome of the test was not significant $(\mathrm{p}<.05)$ and hence, equal variance between the two independent groups was assumed. The results of independent samples t-test are presented in Table 4 for interpretation and discussion. 
The results of the t-test in Table 9 reveal that there was significant statistical difference in the mean academic performance between the two groups of students $(t=-.63, \mathrm{df}=234, \mathrm{p}<.05,2$ tailed).

\begin{tabular}{|c|c|c|c|c|c|c|}
\hline Academic Performance & $\mathbf{N}$ & $\mathbf{M}$ & SD & t-cal & df & $\begin{array}{l}\text { Sig. } \\
\text { (2tailed) }\end{array}$ \\
\hline $\begin{array}{l}\text { Students with } \text { residential } \\
\text { Facilities }\end{array}$ & 84 & 23.5 & 73.7 & -.63 & 234 & .003 \\
\hline $\begin{array}{l}\text { Students without residential } \\
\text { Facilities }\end{array}$ & 152 & 20.7 & 53.4 & & & \\
\hline
\end{tabular}

Source: Field work (2011)

The study findings revealed that students with residential facilities had a higher mean score (M $=23.5, \mathrm{SD}=73.7)$ while students without residential facilities had a lower mean score $(\mathrm{M}=$ 20.7, SD = 53.4). Therefore, students who have access to residential facilities perform better than students who do not have such facilities.

This is because the availability of boarding facilities might provide favourable environment that supports the process of teaching and learning in schools. Thus, students depend on residential facilities to survive academically in school. This corroborates the findings of AffulBroni and Hogrey (2010) and Organisation for Economic Co-operation and Development (2004) that academic performance significantly correlated with the availability of residential facilities. Thus, improvement in residential facilities may also lead to improvement in the academic performance since the students may depend on those facilities.

Research Hypothesis 2: There is no significant relationship between class size and performance of students in Financial Accounting.

Studies have shown that the size of an instructional group has influence on the performance of students in that group. This research hypothesis was formulated to explore whether there is any significant relationship between class size and students' academic performance in Financial Accounting. An attempt was made to collect data on class size. Items 3-6 and 13-16 of the questionnaire for Financial Accounting students and Financial Accounting teachers were employed respectively. The descriptive results are summarised in Table 5.

Table 5: Class Size of Financial Accounting Students

\begin{tabular}{lll}
\hline Class Size & Frequency & Percentage \\
\hline $1-20$ & 0 & 0 \\
$21-40$ & 5 & 2.1 \\
$41-60$ & 145 & 61.5 \\
More than 60 & 86 & 36.4 \\
\hline Total & 236 & 100.0 \\
\hline
\end{tabular}

Source: Field work (2011)

From Table 5, 145 (61.5\%) of the respondents reported that their Financial Accounting classes composed of 41-60 students while only five $(2.1 \%)$ of the students indicated that their class sizes comprised 21-40 students. Also, 86 (36.4\%) of the respondents consented that the number of students in their Financial Accounting classes were more than 60 . The results of the study are indicative of the fact that senior high schools in the Tamale Metropolis that offer 
Financial Accounting have large class sizes because some researchers (Brewer et al., 1999) set it at 17 students while others quote actual class size at 20 students. These large class sizes do not augur well for effective teaching and learning and this might have negative impact on the academic performance of students in Financial Accounting.

Furthermore, simple linear regression analysis was employed to help determine the effect of the independent variable (class size) on the dependent variable (academic performance). The summary statistics are presented in Table 6.

Table 6: Module Summary

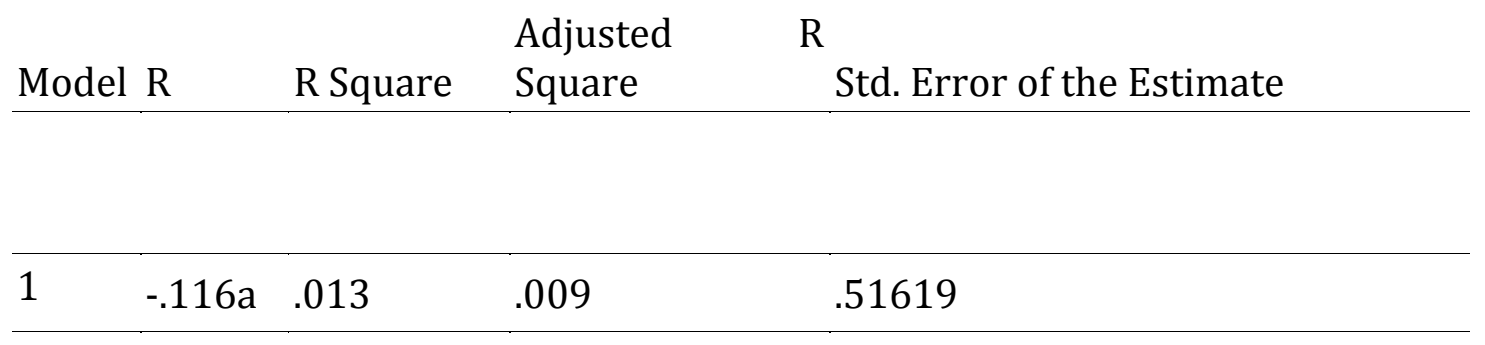

Predictors: (Constant), Performance

Source: Field work (2011)

The results in Table 6 indicate that there is a moderate linear relationship between class size and students' performance in Financial Accounting $(r=-.116)$. The summary model shows that class size, which is the predictor, accounted for only $1.7 \%$ of students' academic performance in Financial Accounting (R Square = .013). This means that the $98.3 \%$ of the variance in students' academic performance in Financial Accounting occurred due to other factors besides the size of the class. This implies school environmental factors; the teachers' level of expertise and experience, availability of instructional materials, students level of motivation, the nature of the learning task among others are the most significant factors that explain for the level of students' performance in Financial Accounting. The result of this current study supports that of Hanushek's (cited in Masden, 2011) study which found no consistent relationship between class size and student achievements as 35 studies reported a weak positive effect of smaller classes.

Table 7: Regression Coefficient of the Relationship between Large Class Size and Students' Performance in Financial Accounting

\begin{tabular}{|c|c|c|c|c|c|c|}
\hline \multirow{2}{*}{\multicolumn{2}{|c|}{ Model }} & \multicolumn{2}{|c|}{$\begin{array}{l}\text { Unstandardized } \\
\text { Coefficients }\end{array}$} & \multicolumn{2}{|c|}{$\begin{array}{l}\text { Standardized } \\
\text { Coefficients }\end{array}$} & \multirow[b]{2}{*}{ Sig. } \\
\hline & & B & Std. Error & & Beta T & \\
\hline \multirow[t]{2}{*}{1} & Constant & 3.595 & .145 & & 24.820 & .000 \\
\hline & $\begin{array}{l}\text { Performa } \\
\text { nce }\end{array}$ & -.004 & .003 & -.116 & -1.785 & .075 \\
\hline
\end{tabular}

The information provided in Table 7 was used to obtain the regression equation which explains expected significant of the level of students' performance with a given class size. The 
regression equation is given as $\mathrm{Y}=3.595-.004 \mathrm{X}$ where $\mathrm{Y}=$ Academic performance and $\mathrm{X}=\mathrm{Class}$ size.

The results in the Table 7 show that there is a weak negative relationship between class size and students' performance although the relationship is not significant $(t=24.82, r=-.116, p>$ .075, 2-tailed).

The results of the study indicate that although large class size can lead to a small reduction in students' performance, such weak and negative relationship is not significant. Thus, when Financial Accounting students in large classes are taught by competent Financial Accounting teachers, who are equipped with the relevant instructional materials, the students stand a better chance of making great gains in their academic pursuits. This contradicts the earlier finding of Glass and Smith (1979), who found that a significant increase in academic achievement require a dramatic reduction in class size. Hence, students of small class sizes will not necessarily perform better if the relevant educational resources (human, material and financial resources) are not secured and supplied to support the teaching-learning process in the classroom.

\section{CONCLUSIONS}

Based on the results of the study, the following conclusions can be made:

Availability of instructional materials has a positive influence on the level of students' academic performance in Financial Accounting. Students who have access to relevant instructional materials such as recommended text books, ICT and library facilities use those materials to supplement their learning endeavours. This will therefore assist them to learn effectively.

The existence of residential facilities can affect students' academic performance. Thus, students in senior high schools with residential facilities have the comfort to concentrate on their studies and this helps to improve upon their academic performance in Financial Accounting.

The number of students in Financial Accounting classes is not a significant determinant of their academic performance in that subject. Thus, with access to adequate and relevant academic and residential facilities, the academic performance of Financial Accounting students in both small and large classes will not differ significantly.

\section{RECOMMENDATIONS FOR POLICY AND PRACTICE}

The following recommendations have been made regarding the results of the study and their pedagogical implications on Financial Accounting at Senior High School Level. It is envisaged that these recommendations, when taken into consideration, would bring about efficiency and effectiveness in the teaching and learning process of Financial Accounting and other related business programmes that are offered at Senior High Schools in Ghana.

In the first place, since instructional materials can help improve students' performance in Financial Accounting, the Ministry of Education in collaboration with the Ghana Education Service should adequately provide all senior high schools that offer Financial Accounting with the necessary instructional materials. Learning materials such as recommended textbooks and pamphlets on Financial Accounting, chalkboard and its equipment, among others, should be provided to schools and this will go a long way to aid the efforts of both students and teachers in the teaching and learning of Financial Accounting. 
Secondly, the government should put policy framework and structures in place in order to provide residential facilities to most day schools, if not all, and provide those schools with the necessary residential facilities. To have a sustained improved academic performance among Financial Accounting students, the government, parents/teachers associations, school management committees and other philanthropists should pool resources together in order to provide senior high schools with ultra-modern residential facilities. These agencies should make conscious efforts to refurbish all boarding schools.

\section{References}

Abosi, C. O., \& Brookman-Amissah, J. (1992). Introduction to education in Ghana. Accra: Sedco Publishing ltd.

Afful-Broni, A., \& Hogrey, P. M. (2010). A comparative study of residential and non residential students' academic performance at the University of Education, Winneba. Academic Leadership, 8 (1), 1-20.

Asiedu-Akrofi, K. (1978). School organisation in modern Africa. Tema: Ghana Publishing Corperation.

Atanda, K., \& Jaiyeoba, A.O. (1998). Conditions of service and job performance of P.T.A. teachers in Ibadan. North local government secondary schools. African Journal of Educational Management ６(1),127-138.

Becta, C. (2002). The impact of information and communication technologies on pupil learning and attainment. ICT in Schools Research and Evaluation Series - No.7: DfES

Best, J. W., \& Kahn, J. V. (1993). Research in education. (7th ed). Toronto: Allyn \& Bacon.

Bourner, T., \& Race, P. (1990). How to win as a part-time student: A Study Skills Guide. London: Inform Publishing Services Ltd.

Brewer, D. J., Krop, C., Gill, B. P., \& Reichardt, R. (1999). Estimating the cost of national class size reductions under different policy alternatives. Education Evaluation and Policy Analysis, 21, 179-192.

Dadzie, E. R. (2010). Ghana needs a long-lasting education policy. Retrieved Feb 23, 2010 from http://www.ghananewsagency.org/

Eshiwani, G.S. (1986). Improving access to education, utilisation of instructional resources,

and utilisation of examinations. Mimeo: Kenyatta University.

Essah-Hienno, F. (2005, September 8). Conference of Heads of Assisted Secondary Schools. Ghanaian Times (No. 273291), p. 6.

Fuller, E. (1985). Effects of teacher qualifications on student achievement in middle school mathematics in Texas. Retrieved November 4, 2011 from https://www.sedl.org/pubs/ 2004.pdf

Glass, V. G., \& Smith, M. L. (1979). Meta-analysis of research on class size and achievement. Educational Evaluation and Policy Analysis, 1 (1), $2-16$.

Hanushek, E.A. (1997). Assessing the effects of school resources on student performance: An update. Educational Evaluation and Policy Analysis, 19(2), 141-164.

Kirk, D. J., \& Jones, T. L., (2004) Effective schools: Assessment report.

Retrieved June 23, 2010, from http://www.pearsonassessments.com

Lezotte, L. (1991). Correlates of effective schools: The first and second generation. Okemos, MI: Effective Schools Products, Ltd.

Lockheed, M. E \& Vespoor,A. M (1991). Improving primary education in developing countries. Oxford; Oxford University Press.

McMillan, J. H. (1996). Educational fundamentals for the consumer. (2nd ed.) New York: Harper Collins.

Ministry of Education (2008). Financial accounting syllabus for senior high schools. Accra: CRDD.

Organisation for Economic Co-operation and Development [OECD] (2004). Boarding schools in the UK

Owoeye, J. S., \& Yara, P.O. (2011). School Facilities and Academic Achievement of Secondary School Agricultural Science in Ekiti State, Nigeria. Retrieved Dec. 5 from www.ccsenet.org/ass.

Sarantakos, S. (1998). Social research (2nd ed.). New York: Palgrave. 
Sowell, E. J. (1989). Effects of manipulative materials in mathematics, Journal of Research in Mathematics Education, 20, 498-505.

Suydam, M. N., \& Higgins, J. L. (1977). Activity-based learning in elementary school mathematics: Recommendations from research. Columbus, OH, ERIC Center for Science, Mathematics, and Environmental Education.

Taba, H. (1962). Curriculum development: Theory and practice. New York: Harcourt Brace and World Inc.

Walstad, W. B., \& Rebeck, K. (2001). Assessing the understanding of U.S.High School Students. American Economic Review, 91(2), 452457.

West Africa Examination Council, (2010). Agenda and papers for the 31st Meeting of Ghana National Aptitude Tests and Examinations committee. Accra. 